KEMAS 16 (3) (2021)402-410
Jurnal Kesehatan Masyarakat

\title{
Environmental Sanitation, Personal Hygiene, STH Co-infection in TB Patients
}

\author{
Nadya Eka Fitri ${ }^{1}$, Diana Chusna Mufida ${ }^{2}$, Bagus Hermansyah ${ }^{3}$, Yunita Armiyanti ${ }^{3}$, \\ Dini Agustina ${ }^{2}$, and Enny Suswati ${ }^{2}$ \\ ${ }^{1}$ Medical Education, Faculty of Medicine, University of Jember, East Java, 68121, Indonesia. \\ ${ }^{2}$ Department of Microbiology, Faculty of Medicine, University of Jember, East Java, 68121, Indonesia. \\ ${ }^{3}$ Department of Parasitology, Faculty of Medicine, University of Jember, East Java, 68121, Indonesia.
}

\section{Article Info}

Article History:

Submitted March 2020

Accepted October 2020

Published March 2021

\section{Keywords:}

Tuberculosis, Co-infection,

STH, Sanitation, Hygiene

DOI

https://doi.org/10.15294/

kemas.v16i3.23639

\begin{abstract}
Globally, helminthiasis is one of the infectious diseases that are often associated with the incidence of tuberculosis. Helminth co-infection modulates the immune system of TB patients by reducing Th- 1 response that functions as protector against Mycobacterium tuberculosis. This condition disrupts the process of eliminating bacteria so that its development becomes more progressive. The impact is the activation of latent TB and the success of TB treatment. A Soil-transmitted Helminth (STH) is a group of intestinal worms that often infect humans. Previous studies prove that environmental sanitation and personal hygiene are risk factors associated with STH infection. The study to determine the relationship of environmental sanitation and personal hygiene with the incidence of STH co-infection in TB patients at Puskesmas Puger, Jember in September until December 2019. This study uses a cross-sectional design. The sampling technique uses total sampling. A total of $32 \mathrm{~TB}$ patients met the criteria as study sample. The data analysis uses Fisher Test. Results showed the prevalence of STH co-infection was relatively low (18.8\%); most of the respondents had good environmental sanitation and personal hygiene conditions. Bivariate analysis showed p-value $(0,476)$ for environmental sanitation and p-value $(1,000)$ for personal hygiene. This study concludes that there is no correlation between environmental sanitation, personal hygiene, and STH co-infection in TB patients at Public health center in Puger.
\end{abstract}

\section{Introduction}

Indonesia has a burden in dealing with tuberculosis cases. The number of TB cases in East Java increased significanly from 20152017. Success rates for TB treatment have tended to decrease since 2008-2017 (Indah, 2018). Jember Regency is second-ranked with TB cases that are still high. TB cases are evenly distributed in 31 districts, such as Puger District (Hikma et al., 2015). Public health center in Puger is one of the health service facilities located in Puger District. The overall number of TB cases in Public health center in Puger has increased by 50\% from 2015-2016. Based on Public health center in Puger's data, TB patients were 361 patients during the 2016-
2019 period. Some cases include recurrence and drug resistant cases.

Low host immunity is one of the factors that can influence the development of Mycobacterium tuberculosis (Chandrasekaran, et al., 2017). This is associated with chronic infections that accompany the disease such as helminthiasis. Studies in Ethiopia shows that $50.5 \%$ of $257 \mathrm{~TB}$ patients suffer from helminthiasis. Helminth co-infection greatly influences the increase of morbidity and decreases the effect of treatment (Kassu, et al., 2015). Based on epidemiological studies that have been carried out in several countries, intestinal helminth infections in TB patients are found in developing countries (Gashaw et

\footnotetext{
Correspondence Address:

Medical Education, Faculty of Medicine, University of Jember, East Java, 68121, Indonesia

Email: chusna.fk@unej.ac.id 
al., 2019; Wong et al., 2019). TB and chronic helminth co-infection interact actively in modulating the immune system. The previous study stated that TB patients who had intestinal helminth co-infection had CD3 +, CD4 +, CD8 +, IL-2, Th-17, Natural killer cells, and IFN $_{\gamma}$ levels lower than TB patients who did not have co-infection (Babu \& Nutman, 2016). Low immune cell production weakens the process of destruction of intracellular bacteria, such as $M$. tuberculosis. Helminth co-infection increases the host Th-2 and T-reg response actively and triggers the production of IL-4, IL-5, IL-10. This condition weakens the Th- 1 response to M. tuberculosis so that bacteria become more progressive and $\mathrm{TB}$ patients are more difficult to healing (Alemu \& Mama, 2017). Previous research stated that intestinal helminth infections also interfere with iron absorption. Iron deficiency decreases hemoglobin levels and the formation of body defense cells, such as macrophages and T cells (Li et al., 2015).

Most helminthiasis in Indonesia is caused by Soil-transmitted Helminth (STH) group with a relatively high prevalence of 20 $86 \%$. STH can infect children to adults with different types of helminths and intensity in each region. STH infections with mild severity often do not show symptoms. Symptoms occur in severe infections and chronically, such as anemia, indigestion, respiratory problems, and cognitive decline. The previous study conducted in Jember Regency stated that STH prevalence was still high, namely above 25\%. Based on Central Statistics Agency's data, Puger District has an area consisting of rice fields and coastal regions, so fishers and farmers are most occupations. The average air temperature is $27-290 \mathrm{C}$ with reasonably high rainfall. This condition is very beneficial for STH's development. Three species of STH that often infect humans are Ascaris lumbricoides, hookworm, and Trichuris trichiura (Apriyan \& Song, 2018)

Environmental sanitation and personal hygiene are two crucial factors that can support helminthiasis. Environmental sanitation is defined as the way to create healthy environment so that the transmission of infection can be reduced, such as hepatitis, helminthiasis, diarrhea and others. Personal hygiene is the way to break the cycle of disease transmission. STH transmission from the environment to humans through contact with the soil while personal hygiene facilitates the transmission of disease through oral-fecal (Martila, et al., 2016).

\section{Method}

The study uses an observational analytic with cross sectional design. The research was conducted at TB Poly, Public health center in Puger and Parasitology Laboratory, Faculty of Medicine, Jember University. The sampling technique uses total sampling. Total sampling is used in populations of less than 100 people. The population was $40 \mathrm{~TB}$ patients who were undergoing active treatment during September-October 2019 and only 32 patients met the criteria. They are patients who are agree to fill an informed concent, collect feces, answer questionnaires, and not including the exclusion criteria. Data sources of this study are primary data and secondary data. Primary data were obtained from respondents. Meanwhile, secondary data was obtained through the patient's medical record (TB status, organs affected, treatment category, and patient's HIV status). The independent variable is environmental sanitation and personal hygiene that were obtained through questionnaires with interview techniques. The dependent variable is STH co-infection that were obtained through feces examination with flotation and sedimentation methods. The questionnaire contained several questions about environmental sanitation and personal hygiene. Environmental sanitation includes feces disposal facilities (latrine ownership); clean water sources, and the type of house floor. Personal hygiene includes defecation habits (BAB), habits of cutting nails, eating habits (consumption of raw food), washing hands habits (before work, after defecation, and before eating), and using PPE habits (footwear or gloves). The tools used for feces examination are feces, lugol solution, MgSO4 salt solution, $10 \%$ formalin, microscopes, centrifuges, objects glass, tube racks, centrifuge tubes, beaker glass, pipettes, sticks, stopwatches, scales, and markers. The data analysis uses univariate and bivariate Fisher. 


\section{Result and Discussion}

Feces are examined and identified at Parasitology Laboratory to determine the presence of STH eggs or larvae. Examination results obtained as many as $6(18.8 \%)$ TB patients had STH co-infection, and 26 (81\%) other patients did not have STH co-infection, as shown in Table 1.

Table 1. Results of Respondent's Feces Examination Tables

\begin{tabular}{ccc}
\hline Feces Samples & Frequency & Precentage (\%) \\
\hline Positive & 6 & 18,8 \\
Negative & 26 & 81,3 \\
\hline Total & 32 & 100,0 \\
\hline
\end{tabular}

Source: Primary data, 2019

The incidence of STH co-infection at Public health center in Puger was relatively low, at only $18.8 \%$. Low prevalence was also shown in previous study that only $7.14 \%$ of 28 samples were helminthiasis (Ayu Parweni, et al., 2019). STH species that infect TB patients at Public health center in Puger are Ascaris lumbricoides and hookworm. The prevalence of A. lumbricoides is higher than hookworm prevalence. This is supported by other research that the incidence of A. lumbricoides infection are higher than hookworm (Eryani, et al., 2014; Syahrir \& Aswadi, 2016). Respondents who were infected by A. lumbricoides have a low education. This is related to the level of knowledge possessed. The personal hygiene of respondents is still relatively low such as eating and using PPE habits. The garbage scavengers were infected by A. lumbricoides do not get used to washing hands, do not use PPE, and carry out their activities in poor working environment so that it supports oral infection (Ruhban \& Rahayu, 2018). Hookworm is the second type of STH that infects TB patients at Public health center in Puger. Their job's activities related to soil. Land in agriculture or plantation areas is loose and full of topsoil because it is managed properly. Hookworm requires sandy soil, many pores (free) soil to develop into an infective. This soil type supports hookworm to get more oxygen (Hairani, 2015).
Table 2. Species of STH through Feces Examination

\begin{tabular}{lcc}
\hline $\begin{array}{c}\text { Soil-transmitted } \\
\text { Helminth }\end{array}$ & N & Percentage (\%) \\
\hline Ascaris lumbricoides & 4 & 66.7 \\
Hookworm & 2 & 33.3 \\
\hline Total & 6 & 100,0 \\
\hline
\end{tabular}

Source: Primary data, 2019

The general characteristics of respondents in this study show that the male respondents are more numerous, namely 18 patients (56.3\%). This gender difference may not affect the incidence of STH co-infection in TB patients at Public health center in Puger. The same study stated that there is no significant results between genders and STH infections but males at risk 1,27 times than females $(\mathrm{OR}=1.27$ ) (Sandy, et al., 2015). Most respondents are 26 and 46 years over. Respondents who experienced STH co-infection are from the adult (26-45) and elderly $(\geq 46)$. Adulthood is often associated with the type of work that has the possibility of ground contact, while the elderly is associated with job history or the ability to maintain personal hygiene which has decreased (Chairil \& Hardiana, 2017; Kusumawardani, 2018). Other reviews mention that STH infections may affect all age groups, especially on environmental sanitation or personal hygiene in poor conditions (Erna \& Mukono, 2015). The highest education level of respondents is from elementary school graduates (50\%). Respondents who had STH co-infection at most primary school graduates. Educational degrees related to person's knowledge. Low level of knowledge causes a person not knowing how to keep environmental cleanliness and personal hygiene so as not susceptible to disease, especially helminthiasis (Marlina \& W, 2012). The study in East Pontianak mention that there was no significant correlation between the level of education with STH co- infection (Lestari, 2014). Respondents who worked as farmers had the greatest prevalence, namely 15 patients $(46,9 \%)$. Six od them was infected 
by STH co-infection. STH infection occurs in work activities related to soil. People who works in mining, plantation, and agriculture are more easily infected because their activities support

Table 3. General Characteristics of Respondents helminth's development. All types of work can be risk of being infected by STH if they do not adopt a clean and healthy lifestyle (Sandy et al., 2015). The data shown in Table 3.

\begin{tabular}{|c|c|c|c|c|}
\hline \multirow{2}{*}{ Characteristics of Respondents } & \multicolumn{2}{|c|}{ Positive } & \multicolumn{2}{|c|}{ Negative } \\
\hline & $\mathbf{N}$ & $\%$ & $\mathbf{N}$ & $\%$ \\
\hline \multicolumn{5}{|l|}{ Gender } \\
\hline Male & 4 & 12.5 & 14 & 43.8 \\
\hline Woman & 2 & 6.3 & 12 & 37.5 \\
\hline \multicolumn{5}{|l|}{ Age } \\
\hline$\leq 11$ & 0 & 0 & 0 & 0 \\
\hline $12-25$ & 0 & 0 & 5 & 15.6 \\
\hline $26-45$ & 3 & 9.4 & 10 & 31.3 \\
\hline$\geq 46$ & 3 & 9.4 & 11 & 34.4 \\
\hline \multicolumn{5}{|l|}{ Education degrees } \\
\hline No school & 0 & 0 & 1 & 3.1 \\
\hline Primary school & 5 & 15.6 & 11 & 34.4 \\
\hline Junior high school & 0 & 0 & 10 & 31.3 \\
\hline Senior High school & 1 & 3.1 & 2 & 6.3 \\
\hline Diploma III & 0 & 0 & 1 & 3.1 \\
\hline Bachelor & 0 & 0 & 1 & 3.1 \\
\hline \multicolumn{5}{|l|}{ Profession } \\
\hline Does not work & 0 & 0 & 8 & 25 \\
\hline Farmer & 4 & 12.5 & 11 & 34.4 \\
\hline Fisherman & 0 & 0 & 2 & 6.3 \\
\hline Labor & 1 & 3.1 & 2 & 6.3 \\
\hline Private sector worker & 1 & 3.1 & 2 & 6.3 \\
\hline Civil servants & 0 & 0 & 1 & 3.1 \\
\hline
\end{tabular}

Source: Primary data, 2019

The characteristics of respondents as TB patients show that most respondents who participated are from new cases (84.4\%) and are received KAT 1 treatment, as many as 27 patients. Respondents suffering from pulmonary $\mathrm{TB}$ recorded more than extrapulmonary with a ratio of $7: 1$, as shown in Table 4. In theory, TB patients who had STH co-infection have a lower Th-1 cell response so that M. tuberculosis' development becomes more progressive. This conditions trigger the growth of latent TB into active TB Patients with active $\mathrm{TB}$ are symptomatic and can be diagnosed clinically, as in new cases (Alemu \& Mama, 2017). Meanwhile, patients with relapsing cases who are infected by STH may never be diagnosed clinically so they are not treated. Prolonged STH infection weakens the patient's immune system and making it difficult for patients healing (Alemu et al., 2019; Gashaw et al., 2019). The number of respondents who suffered from pulmonary tuberculosis is seven times more than extra-pulmonary TB patients because they have seeking treatment at the Public health center in Puger. 
Table 4. Characteristics of Respondents as TB Patients

\begin{tabular}{lcccc}
\hline \multirow{2}{*}{ Characteristics of Respondents } & \multicolumn{2}{c}{ Positive } & N & Negative \\
\cline { 2 - 5 } & $\mathbf{N}$ & $\mathbf{0}$ & & \\
\hline TB Status & & & 23 & 71.9 \\
$\quad$ New Cases & 4 & 12.5 & 1 & 3.1 \\
Relapse Cases & 2 & 6.3 & 0 & 0 \\
Disconnect Drugs & 0 & 0 & 1 & 3.1 \\
MDR & 0 & 0 & 1 & 3.1 \\
Etc & 0 & 0 & & \\
Organ Affected & & & 22 & 68.8 \\
Lung & 6 & 18.8 & 4 & 12.5 \\
Extrapulmonary & 0 & 0 & & \\
Category Medicine & & & 23 & 71.9 \\
KAT 1 & 4 & 12.5 & 2 & 6.3 \\
KAT 2 & 2 & 6.3 & 0 & 0 \\
KAT Modifications & 0 & 0 & 1 & 3.1 \\
MDR & 0 & 0 &
\end{tabular}

Source: Data of Public Health Center, 2019

Based on the score calculation, each element of environmental sanitation is grouped into two categories, as shown in Table 5. The latrine ownership components are categorized as no (not having) and yes (having). There are 6 from 31 respondents (97\%) who already had latrines/toiles are infected by STH. This is in line with the previous research that as many as ten respondents infected by STH already have latrines at home (Kusmi, et al.,2015). The possibility of respondents who have toilets not diligently cleaning toilets and not washing their hands after defecation increases the incidents of STH infection.

The clean water sources components are categorized as river water and dug well water / municipal water work or known as PDAM / others. All respondents have used dug well water / PDAM / others. A total of 6 from all respondents who used dug well water / PDAM / others as water source had STH co-infection.
This result is same with the research that the correlation between clean water facilities and STH infection on elementary school students was not significant $(p=0.109)$ (Nur, et al., 2013). Someone who already uses dug well water or PDAM can be at risk for STH infection if the water is not cooked properly because the water can be contaminated by helminth's eggs or larvae through dirty shelter.

Type of house flooring components are categorized into soil and plaster / ceramic. A total of 29 respondents (91\%) already had plaster / ceramic floor. Five of them infected by STH. These results are in line with Kartini's research that as many as 24 people (14.3\%) whose floors are made of tiles / ceramics suffer from helminthiasis (Kartini, 2016). This can be caused by other factors, such as broken cement floor, not diligently cleaning the floor, not washing hands or feet after work, and not diligently using footwear. 
Table 5. Category of Respondents' Environmental Sanitation Conditions

\begin{tabular}{|c|c|c|c|}
\hline Environmental Sanitation & Positive & Negative & $\mathbf{N}$ \\
\hline \multicolumn{4}{|l|}{ Latrine Ownership } \\
\hline a. No & 0 & 1 & 1 \\
\hline b. Yes & 6 & 25 & 31 \\
\hline \multicolumn{4}{|l|}{ Clean Water Source } \\
\hline a. River & 0 & 0 & 0 \\
\hline b. Dug Well/PDAM/others & 6 & 26 & 32 \\
\hline \multicolumn{4}{|l|}{ Type of House Floor } \\
\hline a. Soil & 1 & 2 & 3 \\
\hline b. Plaster/Ceramic & 5 & 24 & 29 \\
\hline
\end{tabular}

Source: Primary data, 2019

Based on the score calculation, each element of personal hygiene is grouped into two categories. The components of nail cutting, hand washing, eating, and using PPE habits are categorized as bad and good. The component of defecation habits is categorized in gardens / rivers and latrines / toilets. A total of 23 respondents (72\%) had good nail cutting habits, it means respondents diligently maintain cleanliness of the nails and cuts the nails once every 2 weeks. As many as three respondents who experienced STH co-infection have bad nails cutting habits. The pervious study showed that STH eggs or larvae can be stuck between long and dirty nails. Someone who accidentally puts his hand in his mouth can be infected by STH through oral route. Healthy nails means short and clean from the black dirt so that STH is not contaminated (Legese \& Ambelu, 2014)

All respondents who are infected by STH already have a habit of defecating in the latrine / toilet. This result in line with study which states as many as three samples (9.3\%) who have been infected by STH already had defecation habits in toilet (Liena, 2013). Respondents who have defecation habits in the latrine / toilet can be infected by STH if the latrine does not meet health requirements.

A total of 23 respondents (72\%) had a habit of washing their hands properly, it means respondents wash their hands using soap and water. All respondents who had STH coinfection have good hand washing habits. This is not in line with other research that someone who good hand washing properly will be not infected by STH (Irawati, 2013). Respondents may have other bad habits such as eating raw food, not using PPE when their contact with soil, or not being diligent in maintaining nail hygiene.

As many as 17 respondents (53\%) had good eating habits, with details of not being accustomed to eating fresh vegetables, raw meat, and peeling or washing fresh vegetables before consumption. A total of four respondents who have poor eating habits had STH co-infection. If vegetables are watered and treated by fertilizer that contaminated feces, they can contain eggs or STH larvae so they must be washed or peeled before consumption. Meat that is not cooked until cooked also becomes a parasitic nest. Meanwhile, two respondents who were infected by STH already had good eating habits. This may be triggered by other factors, such as not washing their hands before eating, or unclean eating environment.

A total of 20 respondents (63\%) had the habit of using PPE well, it means respondents wear footwear and gloves when dealing with the ground. A total of four respondents who had STH co-infections still did not use PPE well. This is in line with pervious study that between using PPE badly and helminthiasis are significantly related. The use of nonroutine footwear increases STH infection. STH through the soles between the toes, especially hookworm larvae. Workers who do not wear gloves at risk of STH infection are 8,8 times greater than those who wear gloves (Baidowi, et al., 2019).

Bivariate analysis used Fisher's Test because expected count of less than 5 by $50 \%$ (> $20 \%)$. Environmental sanitation and personal hygiene variables are obtained through a questionnaire. STH co-infection are obtained through stool examination. The data analysis 
results are $p=0,476(p>0,05)$ for environmental sanitation and $p=1,000$ for personal hygiene which means there is no significant relationship between environmental sanitation and personal hygiene with STH co-infection events, as shown in Table 7.

The correlation between environmental sanitation with STH co-infection was obtained $\mathrm{p}=0.476(\mathrm{p}>0.05)$ which means there was no significant correlation between environmental sanitation and STH co-infection. This analysis are same the research that found no association between environmental sanitation and STH infection (Nugraha, et al., 2019). Most of respondents who experienced STH co-infection already have the right environmental sanitation conditions. The right environmental sanitation conditions may cause the actual results were not significant.

The correlation between personal hygiene and STH co-infection was obtained $\mathrm{p}=1.000(\mathrm{p}>0.05)$, which means there was no significant correlation between personal hygiene and STH co-infection. The results are in line with the study that there is no significant relation between personal hygiene and the incidence of STH infection ( $\mathrm{p}=0,615)$ (Arifin \& Umiyarni, 2018). The same results were also proven on Adiningsih (2017). Respondents who experienced STH co-infection as many as three people already have good personal hygiene conditions and three others still have poor personal hygiene conditions. This comparison shows equal value so that it can cause no statistically significant differences.

\section{Conclusion}

The conditions of environmental sanitation and personal hygiene of TB patients are good. There is no significant correlation between environmental sanitation, personal hygiene, and STH co-infection in TB patients at Public health center in Puger, Jember $(p>0,05)$.

This study are not analyzing other risk factors that might support STH infections, such as socio-economic conditions, temperature, soil moisture, lighting, bathing habits, sewage irrigation, feces irrigation, animal waste disposal facilities, and garbage disposal facilities. Filling in the questionnaire with interview technique is less sensitive because the possibility of the respondent's answer does not match with the reality and is only based on the respondent's memory. In addition, the researcher did not observe the respondents' daily activities to see the personal hygiene conditions and did not observe the respondents' environmental sanitation conditions.

\section{Anknowledgement}

We would thank the University of Jember that had funded this research [SPK No: 6707/ UN25/LT/2019] September, 2019

\section{References}

Adiningsih, R., Mappau, Z., \& Desitaningsih, N., 2017. The Relationship between Personal Hygiene and Worms Infection in Elementary School Students in Bone-Bone, Mamuju Regency, West Sulawesi. Journal of Health Manarang, 3(1), pp.25-30.

Alemu, G., \& Mama, M., 2017. Intestinal Helminth Co-Infection And Associated Factors Among Tuberculosis Patients in Arba Minch, Ethiopia. BMC Infectious Diseases, 17(1), pp.1-9.

Apriyan, F., \& Song, C., 2018. Prevalence of Soil-transmitted Helminth in Tanah Taman Perumahan, Grogol, Cengkareng, and Kalideres Districts, West Jakarta. Tarumanegara Medical Journal, 1(1), pp.7479.

Arifin, L., \& Umiyarni, D., 2018. Relationship between Personal Hygiene Behavior and Worm Disease Status with Nutritional Status Public Health Center in II Sumbang. Journal Gipas, 2(1), pp.20-31.

Ayu-Parweni.N.K., Getas, I.W., \& Zaetun, S., 2019. Soil Transmitted Helminth Infection of Intestinal Nematode Worms in Green Mustard Vegetable Farmers in Bug-Bug Village, Lingsar District, West Lombok Regency. Analyst Journal of Medika Biosains (JAMBS), 5(2), pp.68.

Babu, S., \& Nutman, T.B., 2016. HelminthTuberculosis Co-infection: An Immunologic Perspective. Trends in Immunology, 37(9), pp.597-607.

Baidowi, I.I., Armiyanti, Y., Febianti, Z., Nurdian, Y., \& Hermansyah, B., 2019. The Correlation Between The Use of Personal Protective Equipment (PPE) and Soil-Transmitted Helminths Infection in th e Workers of Kaliputih Plantation Jember Regency. Journal of Agromedicine and Medical Sciences, 5(2), 
pp.8.

Chairil., \& Hardiana., 2017. Gambaran Perilaku Personal Hygiene Pada Lansia Di Upt Pstw Khusnul Khotimah Pekanbaru. Jurnal Photon, 8(1), pp.29-36.

Chandrasekaran, P., Saravanan, N., Bethunaickan, R., \& Tripathy, S., 2017. Malnutrition: Modulator of Immune Responses in Tuberculosis. Frontiers in Immunology, 8, pp.1-8..

Erna, A., \& Mukono., 2015. The Relationship between Santri Characteristics and Handwashing Habit with the Incidence of Worms in Islamic Boarding Schools in Blitar Regency. Journal of Environmental Health, 8(1), pp.14-24.

Eryani, D., Fitriangga, A., \& Kahtan, M.I., 2014. Personal Hygiene Relationship with Soil Transmitted Helminths Egg Contamination on Nails and Hands of Elementary School Students 07 Mempawah Hilir Pontianak Regency, Jurnal Mahasiswa Fakultas Kedokteran Untan, 6(3), pp.37-57.

Gashaw, F., Bekele, S., Mekonnen, Y., Medhin, G., Ameni, G., \& Erko, B., 2019. High Helminthic co-infection in Tuberculosis Patients with Undernutritional Status in Northeastern Ethiopia. Infectious Diseases of Poverty, 8(1), pp.88.

Hairani, B., 2015. Existence of Mining Worm Eggs and Larvae in Soil in Sepunggur Village and Gunung Tinggi Village, Tanah Bumbu Regency, South Kalimantan, 2014. Journal of Disease Vectors, 9(1), pp.15-20.

Hikma, F., Amareta, D.I., \& Maharani, H., 2015. Mapping of the Distribution of Tuberculosis in Jember Regency in 2013-2015. Indonesian Journal of Health Information Management, 4(1), pp.27-39.

Indah, M., 2018. Tuberculosis. In the Ministry of Health of the Republic of Indonesia, Info Datin, Center for Data and Information.

Irawati., 2013. Personal Hygiene Relationship with Worms in Children in the Work Area of the Public Health Center in Tamangapa Antang Makassar. Thesis, pp.1-107.

Kassu, A., Ergicho, B., Daniel, M.D., \& Elias., 2015. HIV and Intestinal Parasites in Adult TB Patients in a Teaching Hospital in Northwest Ethiopia. October 2007, pp.222-224.

Lestari, T.W., 2014. The Relationship between Knowledge Level, Attitudes and Behavior of Worms Prevention with the Status of Primary School Students 03 East Pontianak Municipality of Pontianak in 2014. Student
Journal of PSPD FK Tanjungpura University, 1(1).

Li, X.X., Chen, J.X., Wang, L.X., Tian, L.G., Zhang, Y.P., Dong, S.P. Zhou, X.N., 2015. Prevalence and Risk Factors of Intestinal Protozoan and Helminth Infections Among Pulmonary Tuberculosis Patients Without HIV Infection In a Rural County in P. R. China. Acta Tropica, 149, pp.19-26.

Liena, S., 2013. Behavior Relationship with Soil Transmitted Helminths Infection in Primary School Children of MI; Asas Islam Kalibening, Salatiga. Journal of Public Health, 4(2).

Marlina, L., \& W,J., 2012. Relationship of Formal Education, Mother Knowledge and Socioeconomic against Soil Transmitted Helminths Infection in Elementary School Children in East Seluma District, Seluma Regency, Bengkulu. Journal of Health Ecology, 11(1), pp.33-39.

Martila, M., Sandy, S., \& Paembonan, N., 2016. The Relationship between Personal Hygiene and Worms in Students at the Public Elementary School in Abe Pantai Jayapura. Journal of Plasma, 1(2), pp.87-96.

Nugraha, T.I., Semiarty, R., \& Irawati, N., 2019. Relationship between Environmental Sanitation and Personal Hygiene with Soil Transmitted Helminths (STH) Infection in School-Age Children in Koto Tangah District, Padang City. Andalas Health Journal, 8(3), pp.590-598.

Ruhban, A., \& Rahayu, A.M.T., 2018. The Relationship of Personal Hygiene and Use of Personal Protective Equipment with Incidence of Worms in Garbage Scavengers at TPA Tamangapa, Makassar City. Jurnal Sulolipu: Media Komunikas Sivitas Akademika Dan Masyarakat, 18(2), pp.122129.

Sandy, S., Sumarni, S., \& Soeyoko, S., 2015. Model Analysis of Risk Factors Affecting Soil-borne Worms Infection in Elementary School Students in Arso District, Keerom Regency, Papua. Media Penelitian Dan Pengembangan Kesehatan, 25(1), pp.1-14.

Syahrir, S., \& Aswadi., 2016. Factors Associated with the Incidence of Worms in Elementary School Students of Inpres no.1 Wora, Wera District, Bima Regency. J. Public health, 2(1), pp.41-48.

Wong, W.K., Mohd-Nor, N., Noordin, R., Foo, P.C., Mohamed, Z., Haq, J.A., \& Lim, B.H., 2019. Parasitic Infections in Malaysian 
Nadya Eka Fitri, et al / Environmental Sanitation, Personal Hygiene, STH Co-infection in TB Patients

Aborigines with Pulmonary Tuberculosis:

A Comparative Cross-sectional Study.
Parasitology Research, 118(9), pp.26352642. 